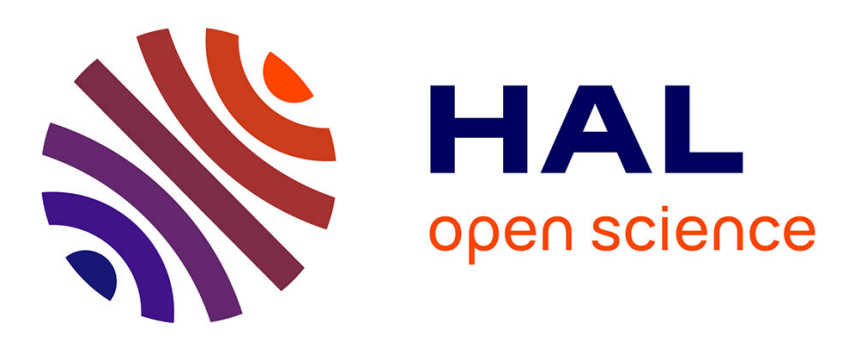

\title{
Hybrid sources control for electric drives traction applications
}

\author{
Mamadou Baïlo Camara, D. Fodorean, David Bouquain, Hamid Gualous, \\ Miraoui Abdellatif
}

\section{- To cite this version:}

Mamadou Baïlo Camara, D. Fodorean, David Bouquain, Hamid Gualous, Miraoui Abdellatif. Hybrid sources control for electric drives traction applications. 2008 International Symposium on Power Electronics, Electrical Drives, Automation and Motion (SPEEDAM), Jun 2008, Ischia, Italy. pp.744749, 10.1109/speedham.2008.4581331 . hal-02994940

\section{HAL Id: hal-02994940 \\ https://hal.science/hal-02994940}

Submitted on 8 Nov 2020

HAL is a multi-disciplinary open access archive for the deposit and dissemination of scientific research documents, whether they are published or not. The documents may come from teaching and research institutions in France or abroad, or from public or private research centers.
L'archive ouverte pluridisciplinaire HAL, est destinée au dépôt et à la diffusion de documents scientifiques de niveau recherche, publiés ou non, émanant des établissements d'enseignement et de recherche français ou étrangers, des laboratoires publics ou privés. 
See discussions, stats, and author profiles for this publication at: https://www.researchgate.net/publication/224321818

\section{Hybrid Sources Control for Electric Drives Traction Applications}

Conference Paper · July 2008

DOI: 10.1109/SPEEDHAM.2008.4581331 · Source: IEEE Xplore

\section{CITATIONS}

14

5 authors, including:

M.B. Camara

Université du Havre

113 PUBLICATIONS 1,752 CITATIONS

SEE PROFILE

D. Bouquain

Université de Technologie de Belfort-Montbéliard

83 PUBLICATIONS 1,094 CITATIONS

SEE PROFILE
READS

185

6. Univiel Fodorean 90 PUBLICATIONS 801 CitaTIONS

SEE PROFILE

Hamid Gualous

Université de Caen Normandie 244 PUBLICATIONS 4,009 CITATIONS

SEE PROFILE

Some of the authors of this publication are also working on these related projects:

Smart Grids Systems View project

Cooperative intelligence for complex traffic environment View project 


\title{
Hybrid Sources Control for Electric Drives Traction Applications
}

\author{
M.B. Camara, D. Fodorean, Member, IEEE, D. Bouquain, H. Gualous, A. Miraoui, Member, IEEE \\ Technological University of Belfort-Montbéliard, Electrical Engineering Department \\ Systems and Transports (SET) Laboratory (France)
}

\begin{abstract}
A judicious study with regard to a more efficient energy management on board of an electric vehicle $(\mathrm{EV})$ is discussed in this paper. This analysis follows the present trend in the field, knowing that the major drawback of the EV is the autonomy problem. Thus, by using a hybrid energy source (formed by ultracapacitors and battery) and with a proper current control (of polynomial type) one can get the proper energy management which will increase the lifetime of the battery. Through numerical simulations and tests at a reduced scale, the authors present a successfully energy management with regard to the $D C / D C$ - battery and DC/AC - electrical machine subsystems operation, used on board of an EV.
\end{abstract}

Index terms - battery, ultracapacitors, electrical machine, control, traction applications.

\section{INTRODUCTION}

$\mathrm{F}$ or vehicle traction systems, three main components can be distinguished: the supplying source (fuel or/and battery), the traction engine (thermal, electric or hybrid ones) and the electric drive (DC/DC or/and DC/AC converters). Due to its poor efficiency and gas emission, the thermal engine will be shortly replaced by the electric car. First steps are already made, the automobile with hybrid motorization being present on the streets in our days. However, the total replacement of the fuelled motors will be certitude only when the supplying problems will be solved. In terms of energy management the research teams are still trying to find the right solution which can assure, to the electric vehicle (EV), autonomy comparable to the thermal vehicle [1]-[5].

In the case of an EV, the main subsystems are (see Fig. 1): the electric source (battery/ultracapacitors or fuel cells), the electric machine (working in motoring as well as in generating regime - for the last case, while recuperative braking occurs) and the control device (DC/DC and AC/DC converter).

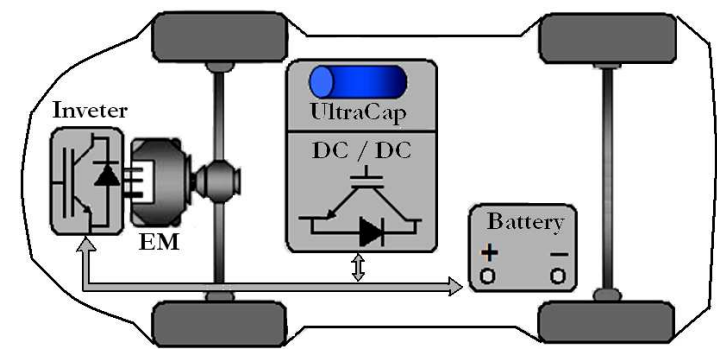

Fig. 1 Electric Vehicle components.
Having a reduced and compact structure, the electric motor placement under the hood can free the space to be used for electric sources (batteries) - even fuel cells can be employed, [6], but this increases the system's complexity and price (issue not discussed here). With regard to the battery, one of the causes which reduce its life time and finally the automobile autonomy is the transient states, due to starting or acceleration mode, where, in a short period of time, an important current is demanded. Thus, for many charging and discharging sequences the battery looses its operability. Therefore, the ultracapacitors (UC) have to be considered, [7], [9]. The UC can assure high currents for a reduced period of time, until the transient is surpassed (and after that it can be recharge).

The goal of this paper is to present a new approach with regard to the energy management on board of an EV. Through simulations, by using the numeric computation linked to the finite element method (FEM) analysis, the readers will see the control efficiency by using polynomial current controllers for the DC/DC converter and the pulse width modulation (PWM) current controllers DC/AC which will feed a load. The obtained results will clearly show that the polynomial and the PWM controllers give satisfactory results. Battery and ultracapacitors discharging states will be simulated numerically and tested on test bench. As a load, it will be considered an electrical motor, meaning a permanent magnet synchronous machine (PMSM) [10]-[12]. Finally, the two subsystems, hybrid energy sources and the load will be joined in order to simulate and test, at reduced scale, the EV behavior.

\section{ULTRACAPACITORS-BATTERY ENERGY EXCHANGE}

The traction chain of the electric vehicle (at reduced scale) comprises a module of ultracapacitors with a maximum voltage of $81 \mathrm{Vcc}$, a source of energy (batteries) with rated voltage $280 \mathrm{Vcc}$, and a $4 \mathrm{~kW}$ electrical machine as a load. The ultracapacitors module is coupled to DC-link by a buck-boost converter which assures the right/optimal energy repartition between the ultracapacitors and the batteries, Fig. 2. The control of these converters depends on the energy management strategy applied between the hybrid sources and the energy requested at the traction chain [7], [8], [10], [13]. 


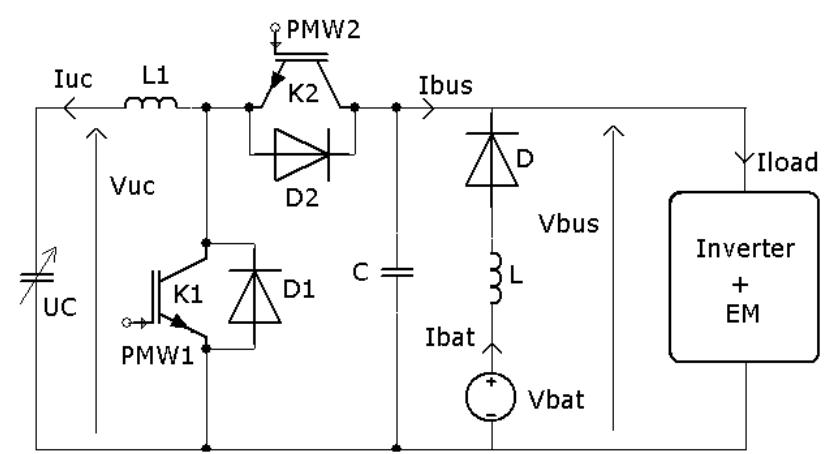

Fig. 2 Controlling system layout.

\section{A. Bidirectional converter modeling}

To establish a general model of the buck-boost converter, it is necessary to analyze the buck and boost modes. During the boost mode the $\mathrm{K} 1$ semiconductor is $\mathrm{ON}$ and the $\mathrm{K} 2$ is OFF and the ultracapacitors module provides energy to the DC-bus. In buck mode, the $\mathrm{K} 2$ is $\mathrm{ON}$ and the K1 become OFF. The ultracapacitors module receives energy from the batteries.

The general analytical model is given by (1), where $\mathrm{k}$ and $\alpha$ define the sign of the ultracapacitors current and the equivalent value of the duty cycle respectively.

$$
\left\{\begin{array}{l}
\mathrm{V}_{\mathrm{L}}=\mathrm{L} \cdot \frac{\mathrm{d}}{\mathrm{dt}}\left(\mathrm{I}_{\mathrm{uc}}\right)=\frac{1}{\mathrm{k}} \cdot\left(\mathrm{V}_{\mathrm{uc}}-\alpha \cdot \mathrm{V}_{\text {bus }}\right) \\
\mathrm{I}_{\text {load }}=\mathrm{I}_{\text {bat }}+\mathrm{k} \cdot \mathrm{I}_{\text {bus }} \\
\mathrm{V}_{\mathrm{L}}=\mathrm{L} \cdot \frac{\mathrm{d}}{\mathrm{dt}}\left(\mathrm{I}_{\text {bat }}\right)=\mathrm{V}_{\text {bat }}-\mathrm{V}_{\text {bus }}
\end{array}\right.
$$

The converter average model has a nonlinear behavior because of crosses between the control variables $\left(\alpha_{1}, \alpha_{2}\right)$ and the state variables $\left(\mathrm{I}_{\mathrm{uc}}, \mathrm{V}_{\text {bus }}\right)$. The $\mathrm{V}_{\text {bus }}, \mathrm{V}_{\mathrm{uc}}, \mathrm{I}_{\text {load }}$, and $\mathrm{V}_{\text {bat }}$ variables are likely to disturb the control. They must be measured and used for the control law estimation and to ensure a dynamics of control.

The bidirectional converter is in buck-mode for

$$
\left\{\begin{array}{l}
\mathrm{k}=-1 \\
\alpha=\alpha_{2}=\frac{\mathrm{V}_{\mathrm{uc}}+\mathrm{V}_{\mathrm{L} 1}}{\mathrm{~V}_{\text {bus }}}
\end{array}\right.
$$

and it is in boost-mode for

$$
\left\{\begin{array}{l}
\mathrm{k}=1 \\
\alpha=1-\alpha_{1}=\frac{\mathrm{V}_{\mathrm{uc}}-\mathrm{V}_{\mathrm{L} 1}}{\mathrm{~V}_{\mathrm{bat}}-\mathrm{V}_{L}}
\end{array}\right.
$$

\section{B. Buck-boost converter control strategy}

The converter control strategy is based in the polynomial dynamic control strategy for energy management between batteries and ultracapacitors. The control strategy must be of current type because the DCbus voltage level is imposed by the batteries.

The buck-boost converter control strategy presents two distinct phases, Fig. 3. The first phase ("1" in the

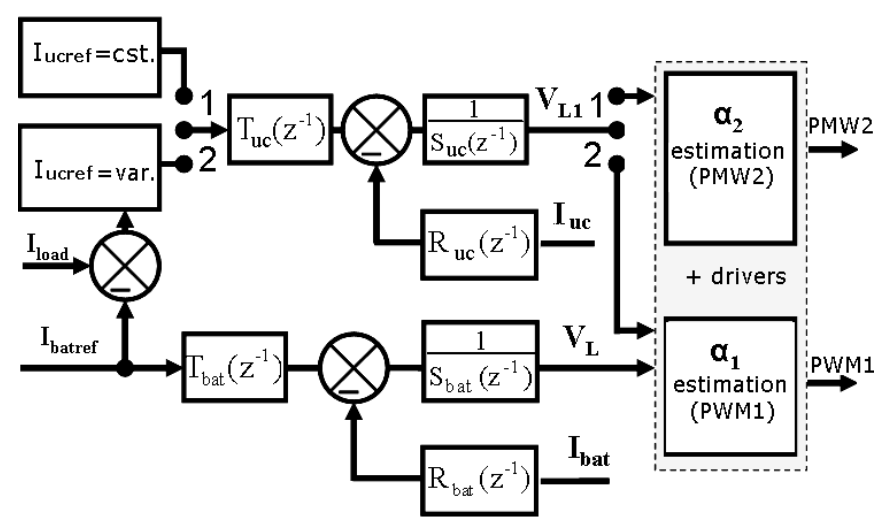

Fig. 3 Converter control strategy.

aforementioned figure) is characterized by the charge of the ultracapacitors with constant current $\left(\mathrm{I}_{\mathrm{ucref}}=\right.$ constant $)$. During this phase, the batteries current loop is not activated, so it can be said that only the PWM2 signal is activated. The second phase (" 2 " in the aforementioned figure) is characterized by the discharge of the UC with a variable current (4), where $0<\eta \leq 95 \%$ is the boost converter theoretical efficiency.

$$
I_{\text {ucref }}=\frac{V_{\text {bus }}}{\eta \cdot V_{\text {uc }}} \cdot\left(I_{\text {load }}-I_{\text {batref }}\right)=\frac{V_{\text {bus }}}{\eta \cdot V_{\text {sc }}} \cdot I_{\text {busref }}
$$

The ultracapacitors reference current $\left(\mathrm{I}_{\text {ucref }}\right)$ is obtained starting from the power management between batteries and ultracapacitors. During this phase the ultracapacitors and batteries current loops with PWM1 control signal are activated. PWM1 and PWM2 signals cannot be activated simultaneously. To obtain a minimal static error with disturbance rejection, the $\mathrm{R}_{\mathrm{uc}}\left(\mathrm{z}^{-1}\right)$, and $\mathrm{S}_{\mathrm{uc}}\left(\mathrm{z}^{-1}\right)$, polynomials of the equation (5) are selected.

$$
\left\{\begin{array}{l}
\mathrm{S}_{\mathrm{uc}}\left(\mathrm{z}^{-1}\right)=1-\mathrm{z}^{-1} \\
\mathrm{~T}_{\mathrm{uc}}\left(\mathrm{z}^{-1}\right)=\mathrm{R}_{\mathrm{uc}}\left(\mathrm{z}^{-1}\right)=\mathrm{r}_{0 \mathrm{uc}}+\mathrm{r}_{1 \mathrm{uc}} \cdot \mathrm{z}^{-1}
\end{array}\right.
$$

In [13] a similar polynomial control strategy was employed with regard to the parallel topology of the DC/DC converter. Here, this technique will be applied to the buck-boost converter.

The coefficients of these polynomials are given by (6), where $\mathrm{L}$ is the ultracapacitors current smoothing inductance, $T_{e}$ is the sampling period and the $\omega_{n}$ is the control strategy band-width. The selected maximum frequency of the band-width is lower than (1/10) of the IGBT control frequency.

$$
\left\{\begin{array}{l}
\omega_{\mathrm{n}} \leq \frac{2 \cdot \pi \cdot \mathrm{f}_{\mathrm{d}}}{10} \\
\mathrm{r}_{0 \text { uc }}=2 \cdot\left(1-\exp \left(-\omega_{\mathrm{n}} \cdot \mathrm{T}_{\mathrm{e}}\right)\right) \cdot \frac{\mathrm{L}_{1}}{\mathrm{~T}_{\mathrm{e}}} \\
\mathrm{r}_{\text {luc }}=\left(\exp \left(-2 \cdot \omega_{\mathrm{n}} \cdot \mathrm{T}_{\mathrm{e}}\right)-1\right) \cdot \frac{\mathrm{L}_{1}}{\mathrm{~T}_{\mathrm{e}}}
\end{array}\right.
$$




\section{Modeling of energy management with UC and battery}

The hybrid system simulations parameters are presented in Table I and the simulations are carried out for boost converter state (PWM1=ON and PWM2=OFF), [8], [14].

TABLE I

HYBRID SYSTEM SIMULATION PARAMETERS

\begin{tabular}{|c|c|c|}
\hline Symbol & Value & Name \\
\hline $\mathrm{f}_{\mathrm{d}}$ & $10 \mathrm{kH} \mathrm{z}$ & IGBT control frequency \\
\hline $\mathrm{V}_{\text {bus1 }}$ & $280 \mathrm{Vcc}$ & DC-link maximal voltage \\
\hline $\mathrm{V}_{\mathrm{uc}}$ & $81 \mathrm{Vcc}$ & Super capacitors maximal voltage \\
\hline$\eta$ & $86 \%$ & Boost converter average efficiency \\
\hline $\mathrm{L}$ & $25 \mu \mathrm{H}$ & Maximal DC-link current \\
\hline $\mathrm{C}$ & $1500 \mu \mathrm{F}$ & DC-link voltage smoothing capacitance \\
\hline $\mathrm{L} 1$ & $50 \mu \mathrm{H}$ & $\begin{array}{c}\text { Ultracapacitors currents smoothing } \\
\text { inductance }\end{array}$ \\
\hline
\end{tabular}

The boost converter simulation results are presented in Fig. 4-Fig. 9. The main goal is to maintain the battery current at a constant value $(10 \mathrm{~A})$ while the system (meaning the ultracapacitors, associate to its converter) will assure the surplus of demanded current.

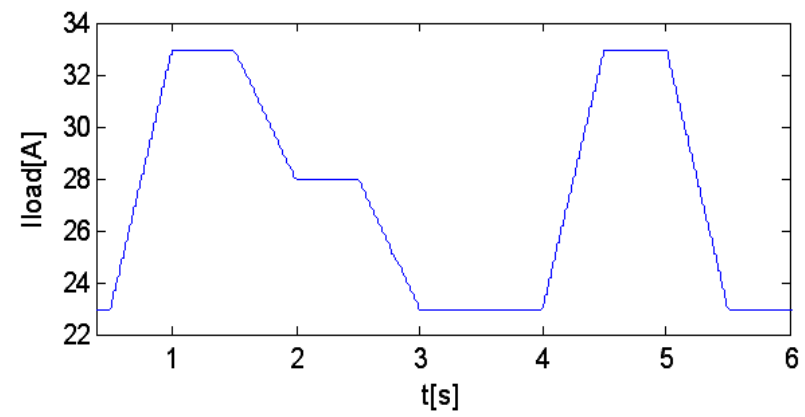

Fig. 4 Active load current profile.
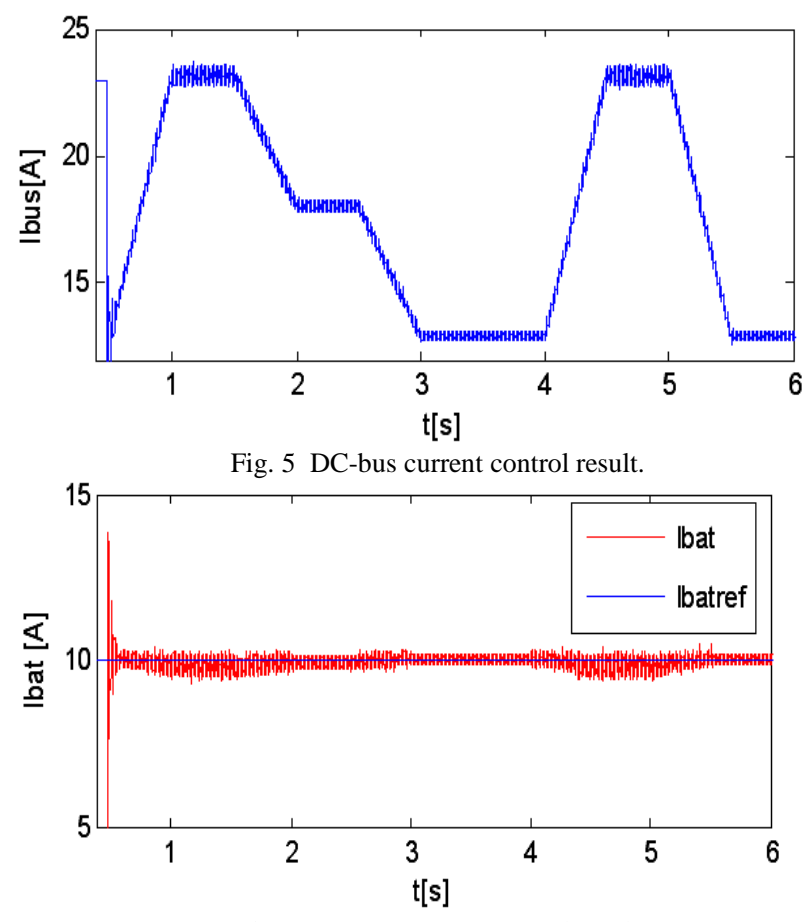

Fig. 6 Battery current control result
In order to verify the control of the boost converters, the battery reference current $\left(\mathrm{I}_{\text {batref }}\right)$ is fixed at $10 \mathrm{~A}$. The active load current $\left(\mathrm{I}_{\text {load }}\right)$ profile is presented in Fig. 4. The simulation results plotted in Fig. 5 and Fig. 6 show that the boost converter control is satisfactory, except the instant around 0.5 second when the current loop do not have enough time to react.

The ultracapacitors module voltage $\left(\mathrm{V}_{\mathrm{uc}}\right)$ is shown in Fig. 7 and its current $\left(\mathrm{I}_{\mathrm{uc}}\right)$ control result is presented in Fig. 8. These results depict that the ultracapacitors current and its reference $\left(\mathrm{I}_{\mathrm{ucref}}\right)$ are practically the same (a smooth control is employed). On the other hand, the DC-bus voltage $\left(\mathrm{V}_{\text {bus }}\right)$ shape obtained by coupling the battery and ultracapacitors cells (the hybrid source) is presented in Fig. 9.

The simulation results (the control which maintain constantly the battery current while the ultracapacitors covers the demand of peak current) give confidence for the implementation of the hybrid energy management system on test bench.

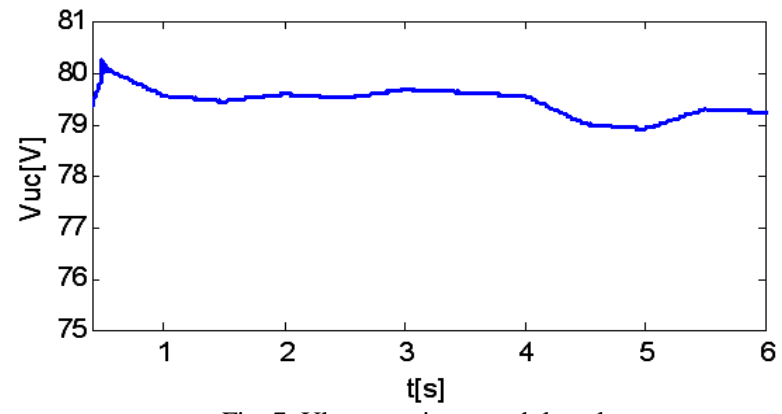

Fig. 7 Ultracapacitors module voltage

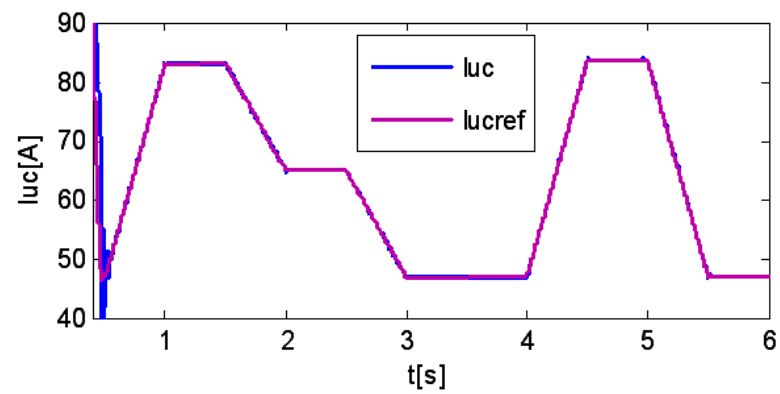

Fig. 8 Ultracapacitors current control result

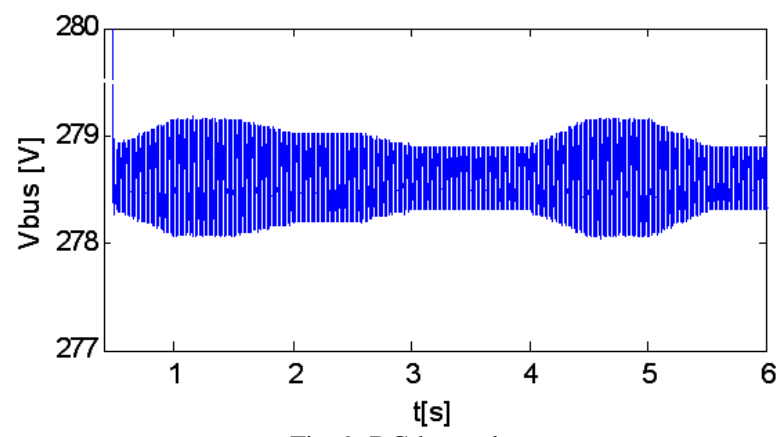

Fig. 9 DC-bus voltage

\section{NUMERICAL CONTROL OF THE PMSM}

In order to simulate the load, a permanent magnet synchronous machine (PMSM) is considered. Numerical 
computation through electrical-mechanical equations gives satisfactory results for specific problems; here, generally, the saturation and losses, as well as electromagnetic parameters variation, are neglected. By taking into account the electric circuit and all the electromagnetic phenomena, and using the finite element method (FEM) computation one can achieve very accurate simulation results which can give confidence for the future tests of the hybrid energy system control for vehicle application. Even if it is time consuming, this analysis is necessary with respect to the estimation of the real MSMP performances; also, some measurements issues can be predicted and operation faults avoided.

The numerical analysis by FEM is implemented on Flux2D software. Moreover, the system control is realized through Matlab/Simulink, thus the real operation conditions are very well fulfilled [1].

The load current profile (from Fig. 4) is the reference current in the modeling system. With a current control strategy, based on pulse width modulation (PWM) technique, one can simulated the system behavior. It is about of $180^{\circ}$ current open-loop control strategy (sinusoidal currents feeding the armature windings). Thus, the control is viewed from the absorbed current ( and finally mechanical torque) point of view, meaning that for a constant speed the load varies.

The system is employed in Simulink. The inverter (Fig. 10a - left) controls the feeding of the PMSM
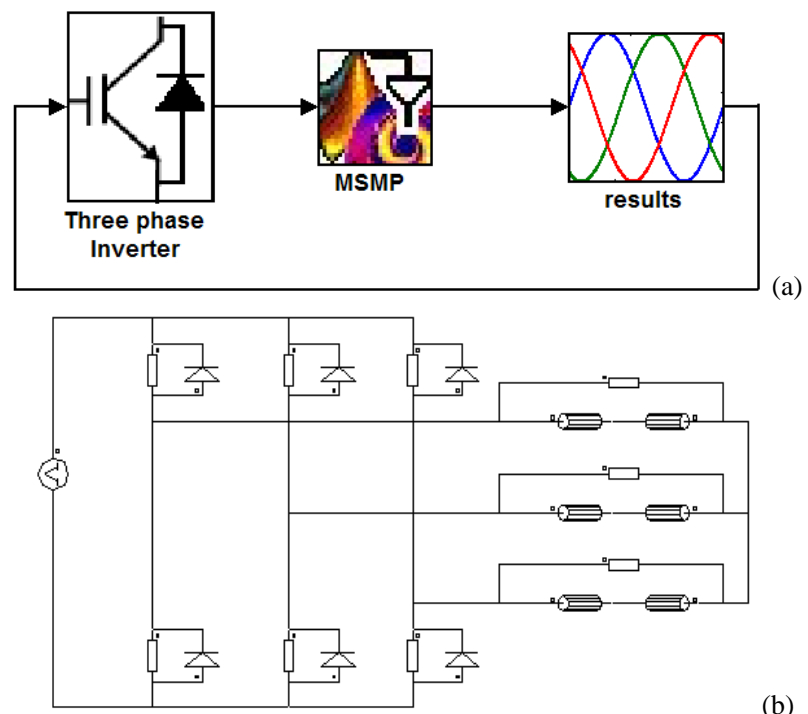

(b)

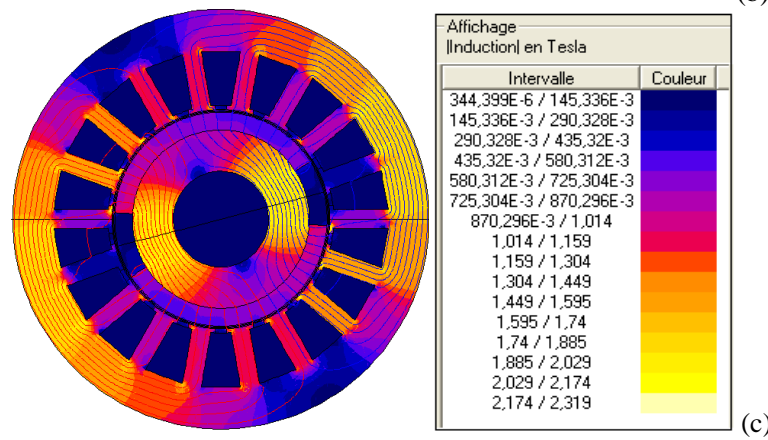

Fig. 10 Numerical analysis of the PMSM: (a) Simulink control system coupled with Flux2D; (b) three phase inverter; (c) field lines and flux density repartition.
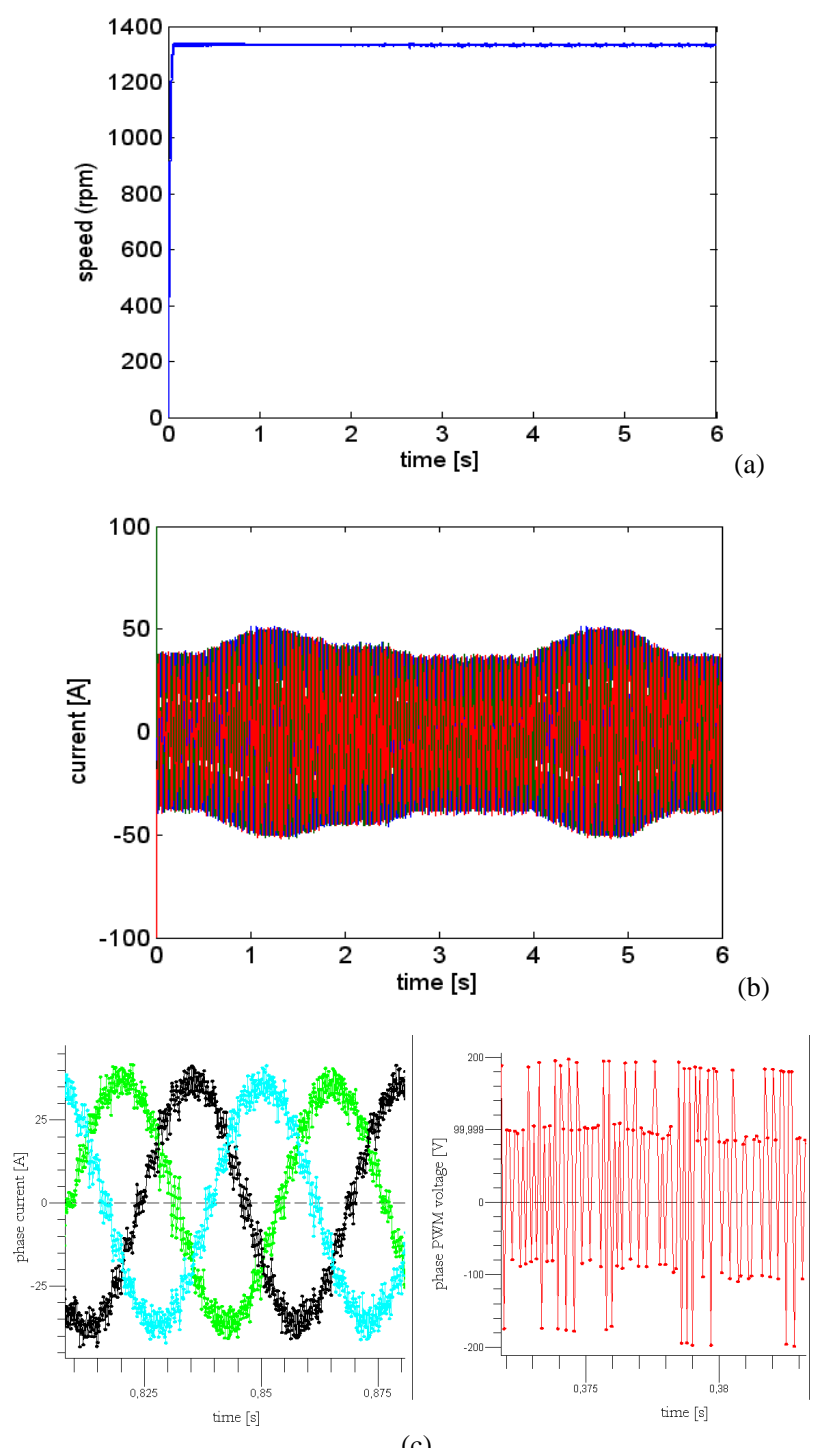

(c)

Fig. 11 Results from numerical analysis of the PMSM: (a) the motor speed; (b) the three phase currents; (c) zoom on PWM voltage and curent.

(Fig. 10a - middle) which is employed in Flux2D, as well as the inverter circuit, Fig. 10b (here, the resistances of $1 \mathrm{e} 6 \Omega$ simulate the voltmeter behavior, or the on/off state of the switches). Among the results, the rotor position is computed and used as loop-parameter, (Fig. 10a - right).

As a sample on the magnetic behavior in the PMSM active parts, one can see the field lines and flux density repartition in Fig. 10c.

More simulated results are given in Fig. 11. Here the speed (Fig. 11a) remains constant, while the current (Fig. 11b) varies with the reference current, $\mathrm{I}_{\text {load }}$ (see Fig. 4). For a more clear view on the current control due to the PWM voltage one can see a zoom of these waves in Fig. 11c.

\section{TESTS}

(Due to some material problem - a non sufficient number of UC cells - the PMSM was replaced by a resistive charge. Consequently, the battery voltage is of 100Vcc.) 
The experimental test bench (Fig. 12) includes two series connected inductances of $25 \mu \mathrm{H}$ (L1 in Fig. 2) used to filter the ultracapacitors current, a pack of ultracapacitors of 30 cells in series connexion to a maximum voltage of $81 \mathrm{Vcc}$ (UC), a battery package of total of $100 \mathrm{Vcc}$ with $13 \mathrm{Ah}$, a buck-boost converter, a capacitor (C) of $6,8 \mathrm{mF}$ for filtering of the DC-bus voltage, an inductance for smoothing the battery current ( $\mathrm{L}$ in Fig. 2) of $25 \mu \mathrm{H}$, and the load. The whole system is controlled by a microcontroller of PIC18F4431 type.

The boost converters tests are carried out in the following conditions: during the ultracapacitors discharge, the batteries current reference $\left(\mathrm{I}_{\mathrm{batref}}\right)$ is fixed at 6 A so that, the ultracapacitors modules provide hybrid vehicle's power request for transient states. For these tests, the hybrid vehicle request $\left(\mathrm{I}_{\mathrm{load}}\right)$ was fixed at $21 \mathrm{~A}$.

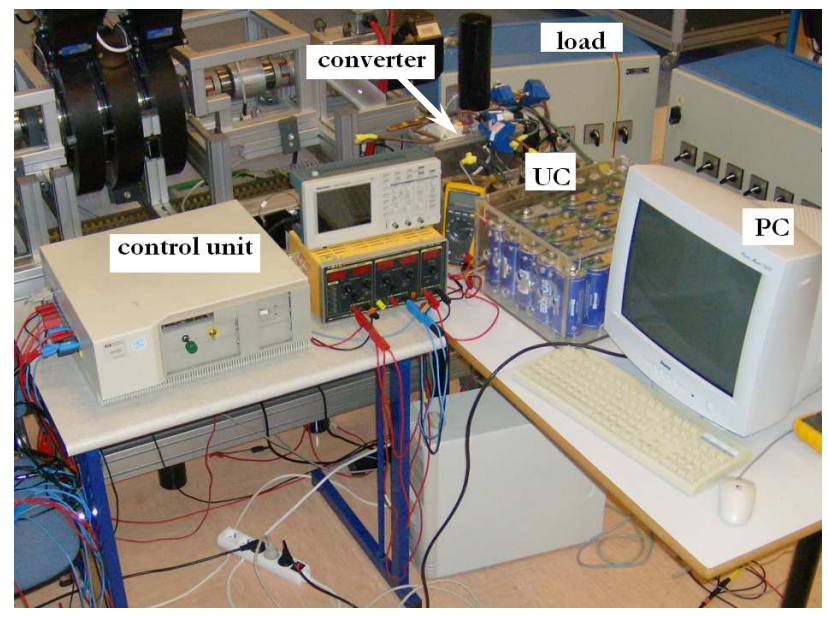

Fig. 12 Experimental setup for UC-battery energy management.

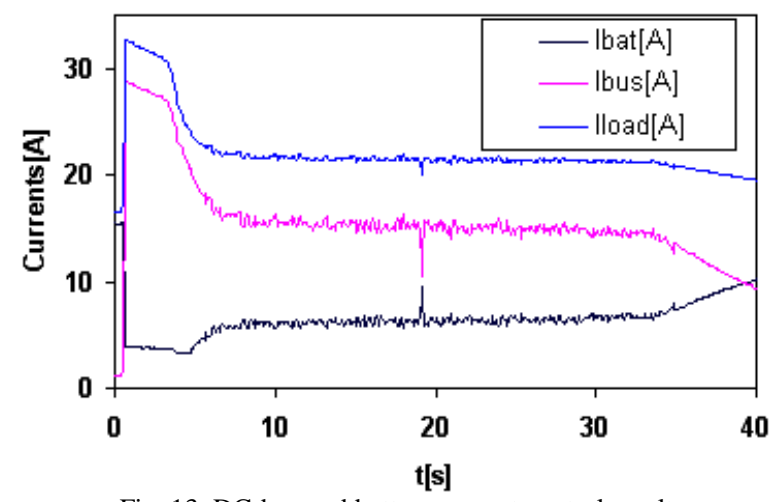

Fig. 13 DC-bus and battery current control result

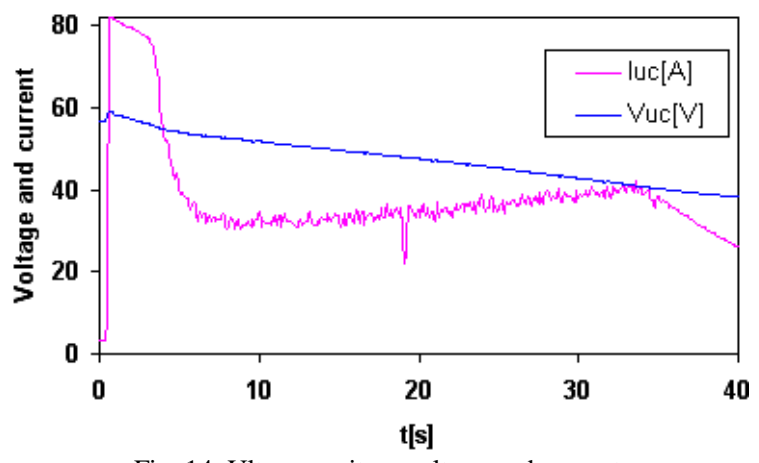

Fig. 14 Ultracapacitors voltage and current

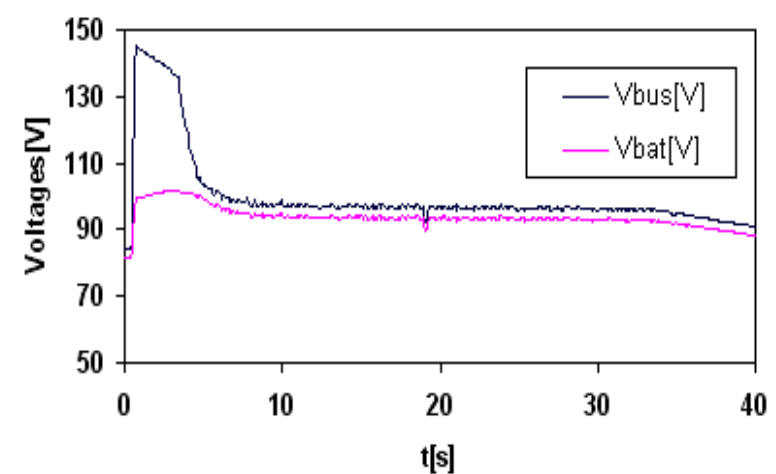

Fig. 15 DC-bus and battery voltages

The Fig. 13 presents the DC-bus current $\left(\mathrm{I}_{\text {bus }}\right)$, battery current $\left(\mathrm{I}_{\text {bat }}\right)$ and the active load current $\left(\mathrm{I}_{\text {load }}\right)$ experimental performances. These results show that the ultracapacitors module assure a current of $15 \mathrm{~A}$ (for $\mathrm{I}_{\text {bus }}$ ) to the hybrid sources DC-bus, and $6 \mathrm{~A}$ only is provided by the battery. (The time elapsed at the beginning of the control process involves the peak of currents and voltages, until the battery are introduced in the electric circuit).

The ultracapacitors current (Iuc) and voltage (Vuc) experimental results are showed in Fig. 14. It can be seen that when the voltage decreases, the current increases in order to maintain constantly the absorbed power, up to 35 seconds, when the UC are no longer useful.

Moreover, experimental results of DC-bus and battery voltages are presented in Fig. 15. Here one can see that the battery voltage is maintained constant up to 35 seconds, until the UC cannot assure, any longer, the necessary absorbed power.

\section{CONCLUSIONS}

This paper presents the energy management study for an electric vehicle traction application. The ultracapacitor-battery energy exchange intermediated through a DC/DC converter, and the battery-electrical machine electric power management through a DC/AC converter are studied analytically, numerically (by finite element method) and on the test bench. With a complete experimental setup (at reduced scale) and by employing a current controllers strategy (polynomial controller) it were obtained successfully results in terms of energy management.

\section{REFERENCES}

[1] Fodorean, D., Djerdir, A., Viorel, I.A. and Miraoui, A. "A double excited synchronous machine for direct drive application - design and prototype tests": IEEE Trans. on Energy Conversion, vol.22, n.3, pp.656-665, September 2007.

[2] Camara, M.B., Gualous, H., Gustin, F. and Berthon, A. "Control strategy of hybrid sources for transport applications using supercondensateurs and batteries", - IPEMC '06, Shanghai, P.R. China, vol. 1, pp.1-5, 13-16 August 2006.

[3] Leedy, A. W. and Nelms, R. M. "Analysis of a capacitor-based hybrid source used for pulsed load applications", Proc of the $37^{\text {th }}$ Intersociety Energy Conversion Engineering Conference '02, pp.1-6, 29-31 July 2002.

[4] Moreno, J., Ortuzar, M.E. and Dixon, J.W. "Energy-Management System for a Hybrid Electric Vehicle, Using Ultracapacitors and 
Neural Networks", IEEE Trans. on Ind. Elec., vol.53, no 2, pp.614623, April 2006.

[5] Schofield, N., Yap, H.T. and Bingham, C.M. "Hybrid energy sources for electric and fuel cell vehicle propulsion", IEEE Conference on Vehicle Power and Propulsion, pp.522-529, 7-9 September 2005.

[6] Gao, L. Jiang, Z. and Dougal, R.A. "Evaluation of active hybrid fuel cell/battery power sources", IEEE Trans. on Aerospace and Electronic Systems, vol.41, no 1, pp.346-355, January 2005.

[7] Cheng, D.L. and Wismer, M.G. "Active Control of power sharing in a battery/ultracapacitor hybrid source", $2^{\text {nd }}$ IEEE Conference on Industrial Electronics and Applications 2007, pp.2913-2918, 23-25 May 2007.

[8] Camara, M.B., Gualous, H., Gustin, F. and Berthon, A. "Design and New Control of DC/DC Converters to share energy between Super capacitors and Batteries in Hybrid Vehicle", IEEE Transactions on Vehicular Technology (in press).

[9] Thounthong, P., Rael, S. and Davat, B. "Control strategy of fuel cell and supercapacitors association for a distributed generation system", IEEE Trans. on Ind. Elec., vol.54, no 6, pp.3225-3233, December 2007.
[10]Barrado, A. Vazquez, R. Olias, E. Lazaro, A. and Pleite, J. "Theoretical study and implementation of a fast transient response hybrid power supply", IEEE Trans. on Pow. El., vol.19, no 4, pp.1003-1009, July 2004.

[11]Fodorean, D., Djerdir, A., Miraoui, A. and Viorel, I.A. "FOC and DTC techniques for controlling a double excited synchronous machine", Proc of the IEEE International Electric Machines and Drives Conference - IEMDC'07, Antalya, Turkye, pp.1258-1263, 3-5 May 2007.

[12]Dong, G. and Ojo, O. "Current Regulation in Four-Leg VoltageSource Converters", IEEE Trans. on Ind. Elec., vol.54, no 4, pp.2095-2105, August 2007.

[13]Camara, M.B. Gualous, H. Gustin, F. and Berthon, A. "Experimental study of buck-boost converters with polynomial control strategy for hybrid vehicles applications", International Review of Electrical Engineering (IREE), vol.2, no 4, pp.601-612, August 2007.

[14]Francoise, J.N.-M., Gualous, H., Outbib, R. and Berthon, A. "42V Power Net with supercapacitor and batterie for automotive applications", Journal of Power Sources, vol. 143, n 1-2, pp.275283, 27 April 2005. 